\title{
A brief review of recent Charcot-Marie-Tooth research and
}

\section{priorities [version 1; peer review: 2 approved]}

\author{
Sean Ekins (1D)-3, Nadia K. Litterman3, Renée J.G. Arnold4-6, Robert W. Burgess7, \\ Joel S. Freundlich ${ }^{8}$, Steven J. Gray ${ }^{9}$, Joseph J. Higgins ${ }^{10}$, Brett Langley ${ }^{11,12}$, \\ Dianna E. Willis ${ }^{11}$, Lucia Notterpek ${ }^{13}$, David Pleasure ${ }^{14,15}$, Michael W. Sereda16,17, \\ Allison Moore ${ }^{1}$
}

\footnotetext{
${ }^{1}$ Hereditary Neuropathy Foundation, New York, NY, 10016, USA

${ }^{2}$ Collaborations in Chemistry, Fuquay Varina, NC, 27526, USA

${ }^{3}$ Collaborative Drug Discovery, Burlingame, CA, 94010, USA

${ }^{4}$ Master of Public Health Program, Mount Sinai School of Medicine, New York, NY, 10029, USA

${ }^{5}$ Quorum Consulting, Inc, San Francisco, CA, 94104, USA

${ }^{6}$ Arnold Consultancy \& Technology LLC, New York, NY, 10023, USA

7The Jackson Laboratory in Bar Harbor, Bar Harbour, ME, 04609, USA

${ }^{8}$ Department of Medicine, Center for Emerging and Reemerging Pathogens, Rutgers University - New Jersey Medical School, Newark, NJ, 07103, USA

${ }^{9}$ Gene Therapy Center and Dept. of Ophthalmology, University of North Carolina at Chapel Hill, Chapel Hill, NC, 27599-7352, USA

${ }^{10}$ Quest Diagnostics, Athena Brand, Marlborough, MA, 01572, USA

${ }^{11}$ Burke-Cornell Medical Research Institute, White Plains, NY, 10605, USA

${ }^{12}$ Department of Neurology and Neuroscience, Weill Medical College of Cornell University, New York, NY, 10065, USA

${ }^{13}$ Department of Neuroscience, College of Medicine, McKnight Brain Institute, University of Florida, Gainesville, FL, 32611, USA

${ }^{14}$ Institute for Pediatric Regenerative Medicine, University of California Davis, School of Medicine, Sacramento, CA, 95817, USA

${ }^{15}$ Department of Neurology, University of California, Davis, School of Medicine, c/o Shriners Hospital, Sacramento, CA, 95817, USA

16Department of Neurogenetics, Max Planck Institute (MPI) of Experimental Medicine, Göttingen, 37075, Germany

${ }^{17}$ Department of Clinical Neurophysiology, University Medical Center (UMG), Göttingen, D-37075, Germany
}

\section{V1 First published: 26 Feb 2015, 4:53 \\ https://doi.org/10.12688/f1000research.6160.1}

Latest published: 26 Feb 2015, 4:53

https://doi.org/10.12688/f1000research.6160.1

\section{Abstract}

This brief review of current research progress on Charcot-Marie-Tooth (CMT) disease is a summary of discussions initiated at the Hereditary Neuropathy Foundation (HNF) scientific advisory board meeting on November 7, 2014. It covers recent published and unpublished in vitro and in vivo research. We discuss recent promising preclinical work for CMT1A, the development of new biomarkers, the characterization of different animal models, and the analysis of the frequency of gene mutations in patients with CMT. We also describe how progress in related fields may benefit CMT therapeutic development, including the potential of gene therapy and stem cell research. We also discuss the potential to assess and improve the quality of life of CMT patients. This summary of CMT research identifies some of the gaps which may have an impact on upcoming clinical trials. We provide some priorities for CMT research and areas which HNF can support. The goal of this

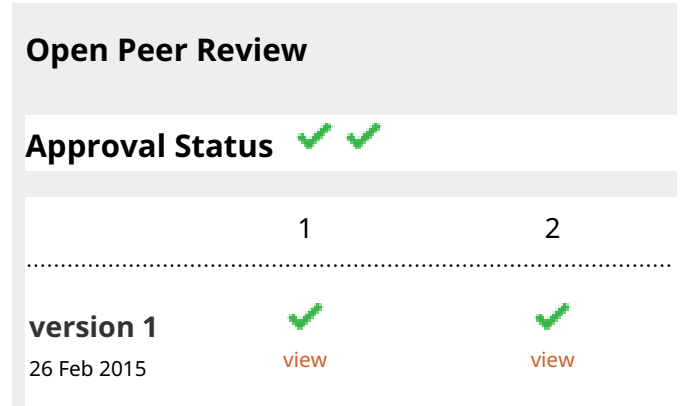

1. Rhona Mirsky, University College London, London, UK

2. Gerard Said, Hôpital Pitié-Salpêtrière, Paris, France

Any reports and responses or comments on the article can be found at the end of the article. 
review is to inform the scientific community about ongoing research and to avoid unnecessary overlap, while also highlighting areas ripe for further investigation. The general collaborative approach we have taken may be useful for other rare neurological diseases.

\section{Keywords}

Charcot Marie Tooth , rare disease , CMT1A , biomarkers , drug

discovery

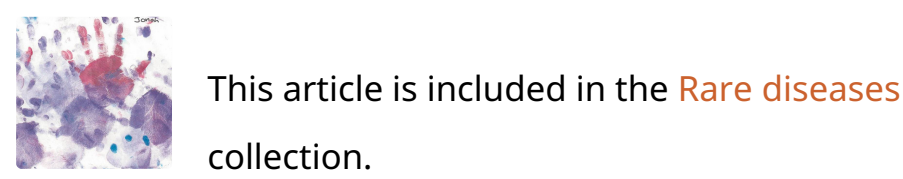

Corresponding author: Sean Ekins (ekinssean@yahoo.com)

Competing interests: SE is a consultant for CDD and employee of HNF, NL is an employee of CDD. JJH is an employee of Quest Diagnostics. HNF receives funding from Pharnext to support CMT education and awareness.

Grant information: The author(s) declared that no grants were involved in supporting this work.

Copyright: (c) 2015 Ekins S et al. This is an open access article distributed under the terms of the Creative Commons Attribution License, which permits unrestricted use, distribution, and reproduction in any medium, provided the original work is properly cited. Data associated with the article are available under the terms of the Creative Commons Zero "No rights reserved" data waiver (CC0 1.0 Public domain dedication).

How to cite this article: Ekins S, Litterman NK, Arnold RJG et al. A brief review of recent Charcot-Marie-Tooth research and priorities [version 1; peer review: 2 approved] F1000Research 2015, 4:53 https://doi.org/10.12688/f1000research.6160.1

First published: 26 Feb 2015, 4:53 https://doi.org/10.12688/f1000research.6160.1 


\section{Introduction}

Several recent reviews have focused on the need for discovery of therapies for rare diseases ${ }^{1}$ as well as the importance of increased collaboration $^{2,3}$. There are few approved treatments for the approximately 7000 rare diseases that affect $\sim 6-7 \%$ of the population of the developed world ${ }^{1}$. Advances in technology are changing how rare diseases are discovered ${ }^{4}$ and deepening our understanding of them $^{5}$. While suggestions on how to increase the number of drugs developed for rare conditions have been made ${ }^{1,6,7}$, it is unlikely that we are going to see a dramatic change unless there is a wholesale shift in the process of drug discovery and development, combined with increased collaboration between academics, industry, government labs and research foundations in the rare disease arena. Perhaps one of the ways this situation can best be changed is if patients and advocates work with the scientists they fund to identify the critical issues that need addressing ${ }^{4,8}$. This may enable developments that are most likely to show some direct benefit for the disease (and patients) to move research from the lab bench to the clinic.

Some rare diseases have recently been in the spotlight for their ability to inspire the raising of large sums of money, which can hopefully accelerate the search for a cure. Most notable is Amyotrophic Lateral Sclerosis (ALS) which became very high profile in 2014 with the ALS ice bucket challenge ${ }^{9}$. For several years there has been a considerable discussion in this scientific community about difficulties translating the many preclinical studies for ALS from the mouse to the very costly human clinical trials ${ }^{10,11}$. It is now apparent that there are several factors that can impact the success of drug discovery even from the very earliest stages, which can in turn influence the transition of new therapeutics into the clinic. When targeting the development of new therapeutics, it is important to consider problematic issues that have prevented success in other disease areas early in the discovery progress. These broader issues can complicate the discovery of new drugs and include: target validation ${ }^{12}$, artifacts such as promiscuous compounds in small molecule screens ${ }^{13-15}$, false positives ${ }^{16}$, how liquids are moved ${ }^{17}$, leaching from plastics used in labware ${ }^{18}$, compound aggregation ${ }^{19}$, the solvent effects ${ }^{20}$, detergent effects ${ }^{21}$, data reproducibility ${ }^{21}$, data quality $^{22,23}$, data access and standards ${ }^{24}$, data handling ${ }^{25}$, and biases introduced by filtering libraries ${ }^{26}$. Even the recent shift of drug discovery from pharmaceutical laboratories to academic screening centers has issues ${ }^{27}$ and major gaps have been identified ${ }^{28}$. Many rare disease foundations or researchers are not even aware of these potential complications, which may ultimately impact the outcome and potential clinical feasibility of the work they fund or pursue, respectively.

We will briefly summarize recent developments in one rare disease, Charcot-Marie-Tooth disease (CMT), and propose further, currently untapped, opportunities as well as ultimately list what we believe should be the priorities for the field. While CMT may not be representative of every rare disease, this example may inspire other groups to consider not only the research they are funding but to go beyond the current dogma and consider what type of research needs to be funded to enable compounds to come to the clinic in the short, mid and long term. Drug discovery is not an overnight process as it usually takes well over a decade to go from a discovery in the laboratory to a product that is approved for clinical use.
The success transitioning from each stage is variable for drugs with orphan designation (with phase 1 and phase 2 success rates above average at 86.8 and $70 \%$, respectively, while the phase 3 success rate at $66.9 \%$ was comparable with all indications $)^{29}$. This would suggest that if we could slightly improve the success of each stage we would see far more drugs approved. We hope that by producing such a summary of recent work and priorities, there will be similar collaborative discussions between researchers and patient organizations for other rare diseases.

\section{Diagnosis and mutations}

Our particular focus is on CMT, a rare disease which has multiple genetic causes ${ }^{30}$ and is classified into nine genetic subtypes (CMT1, CMT2, CMT3, CMT4, CMT5, CMT6, CMTDI, CMTRI and CMTX). Research in many areas is redefining our view of this disease and the complexities involved. CMT affects approximately one in 2500 Americans $^{31}$, who usually have distally pronounced muscle weakness, resulting in difficulty walking and later also gripping objects. Typically, CMT patients display foot deformities, decreased reflexes, and bilateral foot drop ${ }^{32}$. Recent efforts and progress on CMT emphasize that we are steadily and impressively improving our understanding of the complex underlying biology. At the time of writing, there were over 3800 papers in PubMed on this disease. There is however no treatment for any of this group of disorders encompassed by CMT for which symptoms usually present in the first two decades of life ${ }^{33}$, so this presents a huge untapped opportunity to improve the lives of the many patients with this debilitating disease.

Accurate diagnosis of CMT is important if we are to identify patients for future clinical trials with treatments for the disease. Currently a tiered approach to genetic testing is used and recommended by clinicians and relies on nerve conduction velocity assessment, disease inheritance pattern and population frequency ${ }^{34}$. This approach is however laborious, costly and based on recent studies may be ripe for reappraisal. A study in Norway looked at diagnostic laboratory testing for CMT and the spectrum of gene defects in that country $^{35}$. In total, 549 patients were studied. Nearly $96 \%$ of these patients had mutations in just four genes (PMP22, MPZ, GJB1 and $M F N 2)$ linked to CMT. These genetic findings are in accordance with what has also been observed in other countries. In the United Kingdom a study of 1607 patients showed mutations or rearrangements in the same four genes in over $90 \%$ of the samples ${ }^{36}$. In these two studies, patients without a mutation in these four genes were then considered for referral ${ }^{31,37}$. A more recent study in the United States $^{30}$ has evaluated over 17,000 patients using a variety of gene testing methods. The scale of this study is at least 10 times larger than previous analyses and reproduced the finding that almost $95 \%$ of patients had mutations in just four genes. Specifically, it showed that $78.6 \%$ of those tested were positive for copy number variations of PMP22. The genes GJB1, MPZ and MFN2 were present in $6.7 \%, 5.3 \%$ and $4.3 \%$, respectively. These combined studies point to an opportunity for changing the algorithm for CMT diagnosis with initial focus on testing just these 4 genes, and patients that are negative for these can then be evaluated further with nerve conduction velocity testing. Early diagnosis has important benefits as the downstream costs of not treating CMT are considerable, and it can prevent unknowingly exacerbating the disorder by avoiding drugs that are contraindicated. 
New CMT mutations are also continually being sought which may help with diagnosis and biological understanding of the disease. This is particularly important in CMT2, in which, unlike CMT1A, the most common mutations (MFN2 and GDAP1) account for only $25 \%$ of the total. Next generation sequencing (NGS) was used to screen CMT2 genes in 15 patients in whom MFN2 and GDAP1 mutations were excluded ${ }^{38}$. A new mutation in $H S P B 1$ was identified, a c.404C $>$ A transversion resulted in p.(Ser135Tyr) amino acid change. A previous p.(Ser135Phe) HSPB1 mutant was found to impact cell viability and neurofilament assembly in cultured cell experiments $^{38}$. It is highly likely that the newly discovered mutation has a similar if not identical role. It was suggested that NGS is a tool for efficient mutation detection and exclusion in $\mathrm{CMT}^{38}$.

The role of aminoacyl-tRNA synthetases (ARS) has recently been reviewed as housekeeping enzymes ${ }^{39}$. That is to say ARS have a key role in ensuring accurate transfer of information in the genetic code. Mutations in GARS (glycyl-tRNA synthetase gene), KARS (lysyltRNA synthetase gene), AARS (alanyl-tRNA synthetase gene) and YARS (tyrosyl-tRNA synthetase gene), all are definitively associated in causing axonal CMT ${ }^{40-43}$. Furthermore, evidence supports the additional association of lysy'-tRNA synthetase, methionyltRNA synthetase and histidyl-tRNA synthetase in peripheral axon degeneration $^{44,45}$. For example CMT2D is an axonal neuropathy characterized by a phenotype that is more severe in the upper extremities. Mutations in the gene encoding GARS have been implicated in CMT2D. Mutations in GARS show loss-of-function features ${ }^{46,47}$, suggesting that tRNA-charging deficits play a role in disease pathogenesis, but animal studies support a gain of function mechanism ${ }^{47,48}$. Yet the linkage between mutations and subsequent pathology is unclear. It is difficult to reconcile the mutations in these enzymes with CMT, and numerous possible etiologic mechanisms from loss-of-function to gain-of-function including many that may be outside their usual role ${ }^{49}$. The latter may be outside their usual role. Yao and Fox ${ }^{39}$ also describe the role of the ARS proteins in other organisms such as yeast and bacteria as well as drug targets (e.g. antitumor). This should be considered in light of possible complications one sees with other chemotherapeutic agents precipitating CMT. This would be a very important consideration if ARS were to be targeted for modulating various diseases and hints at the potential of how biological discoveries in one area like a rare disease can shed light on many other diseases at little extra cost.

\section{Basic research: recent Charcot-Marie-Tooth preclinical research}

The progress of CMT has been described in several steps recently ${ }^{50}$. Genetic defects in myelinating Schwann cells (e.g. PMP22 duplication, CMT1 $\mathrm{A}^{30,51}$ or overexpression leads to missorting or the accumulation of these mutated/overexpressed proteins. In addition to subsequent demyelination, the malfunctioning Schwann cells then fail to sustain axonal support which results in progressive axonal and neuronal loss. The clinical phenotype of CMT is ultimately determined by the resulting neurogenic muscle atrophy.

Several recent papers provide some encouraging news in the quest for treatments for CMT1A, which is a primary dysmyelinating disease, and have identified compounds that have reached preclinical or clinical stages (Table 1). In addition to these, one study described how the CMT1A rat model (in early postnatal development) could be treated with a recombinant human growth factor called neuregulin-1 which controls myelin thickness ${ }^{52}$. In CMT rats this appears to enhance the reduced signaling of phosphatidylinositol 4,5-bisphosphate 3-kinase (PI3K)-v-Akt murine thymoma viral oncogene homolog 1 (Akt) and lower augmented mitogen-activated protein kinase kinase 1 (Mek)-mitogen -activated protein kinase (Erk), and is able to improve the differentiation of Schwann cells in CMT1A. Thus, neuregulin-1 can counter the effect of PMP22 overexpression on downstream signaling. Neuregulin-1 was found to be less effective in treating older animals. This approach may be useful in children where it could be applied before disease onset. This work opens the door for using compounds that modify signaling pathways and the kinases involved.

A second recent paper used genome editing to create an assay for high throughput screening to expand the targets for drug discovery in $\mathrm{CMT}_{1} \mathrm{~A}^{53}$. The main result of this work was the identification of the protein kinase $\mathrm{C}$ modulator bryostatin (Table 1) which lowers PMP22 expression. Interestingly this compound was not identified in previous screens by the group which had delivered the proteasome inhibitors such as bortezomib ${ }^{54}$ (Table 1). In summary, two independent groups have now focused on the role of kinases in pathways that control PMP22. This work may foster a broader consideration of the many compounds already available that modulate different kinases.

Alternative approaches in ameliorating the disease phenotype in CMT1A have focused on protein quality control mechanisms, specifically autophagy and chaperones. Rapamycin, a calorie restriction mimetic was shown to improve myelination in neuronSchwann cell explant cultures from neuropathic mice, however this drug did not improve neuromuscular performance in mice in vivo ${ }^{55}$. The differential response of skeletal muscle and peripheral nerve tissue to rapamycin is hypothesized to be responsible for the lack of functional improvement in neuropathic mice. Additional efforts in identifying therapeutic target pathways for CMT1A neuropathies involve studies on the normal function of PMP22 in myelin. A novel role for PMP22 has been found in the linkage of the actin cytoskeleton with the plasma membrane, possibly through regulating the cholesterol content of lipid rafts ${ }^{56}$.

Other targets of interest for CMT include histone deacetylase 6 (HDAC6) $^{57}$ as the inhibition of this can promote survival and regeneration of neurons. It was more recently shown that an increase of $\alpha$-tubulin acetylation induced by inhibition of HDAC6 corrected axonal transport defects caused by HSPB1 mutations, rescued the CMT phenotype of mutant HSPB1 mice ${ }^{58}$.

One of the ways that some CMT patients first become aware of their disease is when they are given a drug treatment for another disease. This is termed chemotherapy-induced neurotoxicity. Drugs such as paclitaxel and the vinca alkaloids that are widely used in cancer treatment cause severe peripheral neuropathy and in some patients, this exacerbates CMT, revealing it perhaps for the first time. There have been recent developments in this area that may protect CMT patients in the future. A synthetic antioxidant called ethoxyquin ${ }^{59}$, which was approved by the US Food and Drug Administration 
Table 1. Compounds tested for CMT 1A (impacting Pmp22) in vitro and or in vivo. (All structures were extracted from ChemSpider (www.chemspider.com)).

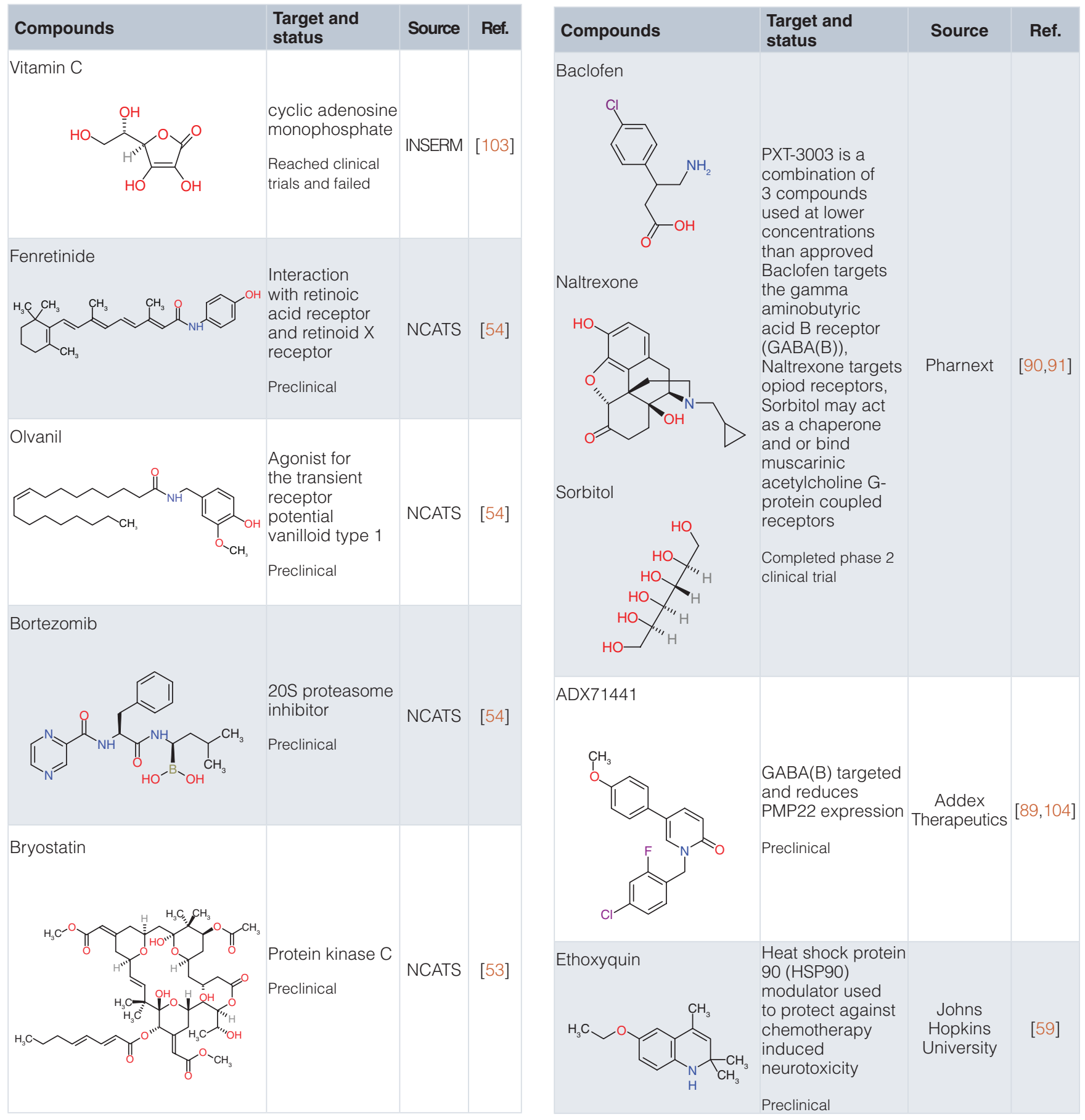


(FDA) 50 years ago, appears to protect against neurotoxicity in both cell and animal studies. This treatment does not appear to impact chemotherapy and also modulated a protein called heat shock protein 90 (HSP90). This work paves the way for further studies of the neuroprotective ability of this and other compounds and possibly clinical trials for patients with pre-existing CMT that need to undergo chemotherapy and for which there are few options. At the same time it may help reveal the mechanisms of neurotoxicity resulting from these chemotherapeutics. A recent study described how inducible HSP70 prevented aggregation and enhanced the processing of PMP22. The authors also proposed the further study of HSP90 inhibitors in models of PMP22-linked neuropathies ${ }^{60}$.

\section{Basic research: new animal models}

The creation of mouse models for CMT can be used to understand the mechanisms of the various types of this disease and for drug discovery $^{61}$. Three mouse models of CMT1X, CMT1B and CMT1A were recently developed to study Schwann cells and show that they display a heterogeneous pattern of developmentally regulated molecules $^{62}$. These could be useful for diagnostic purposes. They also described an inflammatory reaction as a common disease modulator in the mouse and possibly humans with CMT1. LRSAM1 is a E3 ubiquitin ligase and mutations in LRSAM1 have recently been shown to cause CMT. Mouse mutations in Lrsam1 were created for a form of CMT (CMT2P) which had only a very mild neuropathy phenotype with age but was more sensitive to the neurotoxin acrylamide, causing axon degeneration ${ }^{63}$. LRSAM1 primarily localizes in a perinuclear compartment immediately beyond the Golgi, but its cellular function is not yet understood. However, the phenotype of the Lrsam 1 mutant mice is so mild that it is of questionable utility as a disease model, and similar findings in genes such as Hintl highlight the challenges of creating valid mouse models of axonal neuropathies ${ }^{64}$.

While we frequently see groups use mice and rat as animal models of diseases, sometimes they are unsuitable for knocking out genes as they can result in embryonic lethality. The zebrafish has been described as a model of CMT2A which affects the distal axons of motor and to a lesser extent, sensory neurons in humans ${ }^{65}$. The study assessed the phenotypic effects of mitofusin 2 (MFN2) mutation in zebrafish. The $M f n 2$ mutant zebrafish do not develop abnormalities until later stages. Previously it had been shown by others that knocking out the MFN2 gene in mice resulted in embryonic lethality. Zebrafish created with this mutation in MFN2 developed normally, however they showed a progressive motor dysfunction as the fish were unable to swim correctly between 100 and 200 days ${ }^{65}$. Some patients with mutation of the MFN2 gene also show this progressive motor dysfunction. Fishes were monitored in the study ${ }^{65}$ by video in their aquarium and those swimming at an angle of more than 30 degrees to the horizontal were specifically recorded ${ }^{65}$. In addition to these studies, in vitro cell culture was utilized to measure the mitochondrial transport in the neurons from the MFN2 knock out zebrafish and it was found that retrograde transport was decreased. Obviously, while humans and zebrafish appear dissimilar, their MFN2 proteins are very similar. This study therefore presents a potentially very useful animal model of CMT2A that can then be explored to test potential future drugs for their effect on mitochondrial dynamics and axonal transport in order to see if they can ameliorate the phenotype (swimming at an angle of more than 30 degrees) observed.

When we think of the different animal models for diseases like CMT, the fruit fly (Drosophila melanogaster) is likely the furthest from our mind. Yet the fruit fly has quite possibly overturned our basic understanding of the disease mechanism behind CMT2B, by becoming the first animal model for this disease. CMT2B was long thought to be a "gain of function" disease. A recent study however showed that neurons lacking a gene for $r a b 7$ result in neuropathy, while addition of Rab7 proteins could restore function ${ }^{6}$. Fundamental insights like this can affect how we approach a treatment or cure for CMT2B. Perhaps experimental methods to increase Rab7 protein levels, while opposite to the previous dogma, may actually be correct. There are still multiple hurdles to overcome because the fruit fly may not be a perfect disease model for human CMT2B. A second paper also suggests that the human Rab7 mutation mimics CMT2B in the fly ${ }^{67}$. In this study, a second fly model was developed and demonstrated attributes of the human disease. Flies have also been successfully used to model neuropathy associated with tRNA synthetases and to identify genetic modifiers of these diseases ${ }^{68,69}$. This model could be useful for screening compounds as potential therapies and understanding of the mechanism of the disease. This also represents another case of flies being useful of humans. The increasing utilization of different animal models of various CMTs suggests that their role will likely increase in importance and may lead to useful insights and help identify therapeutics.

\section{Basic research: gene therapy and stem cells}

There have been relatively few studies assessing gene therapy for CMT. One group recently used neurotrophin-3 (NT-3) gene therapy via adeno-associated virus (AAV) delivery to muscle ${ }^{70}$. In the Trembler-J model of demyelinating CMT, this gene therapy led to measurable NT-3 secretion and improved motor function, histopathology, and electrophysiology of peripheral nerves.

Other hereditary neuropathies have also been the subject of gene therapy. For example Giant axonal neuropathy (GAN) is caused by loss of function of the gigaxonin protein. In cells this is seen as intermediate filament (IF) aggregation, and leads to a progressive and fatal peripheral neuropathy. GAN mice received an intracisternal injection of an AAV9/GAN vector to globally deliver the GAN gene to the brainstem and spinal cord. These mice showed clearance of peripherin IF accumulations suggesting that gigaxonin gene transfer can reverse the pathology ${ }^{71}$. Other dominant CMTs may be best approached with allele-specific knockdown methods to try to eliminate the expression of the mutant mRNA. Piloting such approaches in CMT represents another way in which CMT translational research could have a broader impact for other rare diseases.

Induced pluripotent stem cells (iPSCs), which offer an unlimited supply of cells derived from adult patient cells, offer a unique opportunity for human disease modeling and investigation. After reprogramming, iPSCs can be differentiated into many different cell types including neurons and glia, which has led to important findings for 
understanding disease mechanisms and therapeutic approaches ${ }^{72-75}$. For example, the derivation of iPSCs from three GAN patients with different GAN mutations was recently reported and key pathological phenotypes observed. These cells were used to support the feasibility of gene replacement therapy ${ }^{76}$. iPSC-derived motor neurons from axonal CMT patients identified common pathophysiological mechanisms in axonal CMT2A and CMT2E ${ }^{77}$. Differentiation of CMT iPSCs into Schwann cells, which are most affected cell type in CMT, will be an important next step. Despite progress recapitulating Schwann cell developmental stages, improvement of differentiation protocols is still required to achieve mature, functional Schwann cells with high efficiency ${ }^{78-80}$.

\section{Basic research: improving collaboration and using computational approaches}

We have previously described how research collaborations may enhance drug discovery and how computational approaches can be used to facilitate secure sharing of data between collaborators ${ }^{81,82}$. The NIH Blueprint Neurotherapeutics Network ${ }^{83}$ is one example which provides support for small molecule drug discovery and development, access to NIH-funded contract research organizations (CROs), and access to consultants with expertise in various aspects of drug discovery and development. At the center of this is secure collaborative software so that molecules and screening data with intellectual property IP are securely shared between the groups of collaborators ${ }^{84}$. With the various screening efforts undertaken for CMT1A to date ${ }^{53,54}$ perhaps it is also worth considering using computational approaches to help identify additional compounds to test using machine learning models built with the data $^{85}$. Also considering some of the "molecule-centric" issues in drug discovery, the potential compound libraries to be tested could be filtered before HTS for potential PAINS ${ }^{13}$, false positives, aggregators, etc. As there has been considerable investment in developing chemical probes from various screens of the NIH MLSMR library, assessment by an experienced medicinal chemist has created a score which has been used to derive a computational model ${ }^{86}$. This could also be used to provide some idea that the molecule may also be reasonable to a medicinal chemist's perspective.

\section{Clinical research: CMT biomarkers and natural history of disease}

New clinical biomarkers are needed for CMT. Recently a novel magnetization transfer ratio (MTR) MRI assay of the proximal sciatic nerve $(\mathrm{SN})$ was developed as a potential biomarker of myelin content changes in patients with CMT diseases ${ }^{87}$. The relationship between MTR and clinical neuropathy scores was assessed. Mean volumetric MTR values were significantly decreased in the SN of patients with CMT1A and CMT2A relative to controls. Skin derived mRNA expression also holds promise to serve as biomarkers in CMT1A patients ${ }^{61}$.

The international Inherited Neuropathy Consortium (INC) recently analyzed clinical and genetic data from 1652 patients evaluated at 13 INC centers ${ }^{88}$. The disease burden of all the mutations was assessed by the CMT Neuropathy Score (CMTNS) and CMT Examination
Score (CMTES). Five subtypes of CMT (CMT1A/PMP22 duplication, CMT1X/GJB1 mutation, CMT2A/MFN2 mutation, CMT1B/ $M P Z$ mutation, and hereditary neuropathy with liability to pressure palsy/PMP22 deletion) accounted for $89.2 \%$ of all genetically confirmed mutations. The study also confirmed that patients could be uniformly assessed between international centers and provides a baseline for future clinical studies.

Clinical research: clinical trials and outcomes research We have recently described some of the compounds for CMT in preclinical $^{52,89}$ or clinical trials. Two recent publications from Pharnext described the novel combination of three drugs called PXT-3003 and their effect on CMT1A both in the $\mathrm{lab}^{90}$ and in a phase 2 clinical trial ${ }^{91}$. Initially three drugs approved for other uses (baclofen, naltrexone and sorbitol) were tested separately and were shown to work better at increasing myelination in Schwann cells when combined together in the test tube (at concentrations far lower than their approved doses). The combination of the three drugs was shown to lower Pmp22 expression. In the rat model of CMT1A different measures of effectiveness suggested that PXT-3003 was also promising and likely efficacious. The very low doses of all three components would also negate any adverse side effects. The clinical trial used three dose levels of PXT-3003 in 80 adults with mild to moderate CMT1A. This trial confirmed the safety of the combination drug and the best improvement was seen at the highest dose. No adverse events were observed. Efficacy was also assessed using the CMTNS and Overall Neuropathy Limitations Scale (ONLS). While a relatively modest but statistically significant improvement was observed, this represents the most promising potential treatment to date surpassing the various clinical trials of ascorbic acid (vitamin C), which showed less change from baseline than high dose PXT-3003. There are still many gaps in understanding the mechanism of how PXT-3003 actually exerts its effect. It is hoped that looking at patients over a longer period and possibly treating them earlier before they become clinically affected by the disease, may improve their nerve conduction. PXT-3003 represents the most promising therapeutic for the disease in years but there is still a long way to go (several years at least as PXT-3003 will enter phase 3 clinical trials in 2015) before it may be more widely available as an FDA or European Medicines Agency (EMEA) approved treatment for CMT1A.

What do we need for this and other clinical trials to be successful? The dependence on relatively crude outcome measures like the six minute walking test etc. which are still relied on need updating with technologies which track the patient continually ${ }^{92,93}$, rather than during a visit to the neurologist. New measures or biomarkers could perhaps be developed and applied in clinical trials for $\mathrm{CMT}^{94}$. In addition, more subtle analysis based on surveying the patient and the caregiver may also be instructive.

For example, if we are to learn more about CMT and the effectiveness of rehabilitation it is worth involving the patient and their caregiver. A recent Italian study described a survey of CMT patients and caregivers and their perspectives and perceptions of rehabilitation efficacy and needs ${ }^{95}$. This cross-sectional study used several 
standard questionnaires to survey 123 patients enrolled through clinical and genetic testing. Not surprisingly, the results suggested that patients believe it is important to feel better after physical therapy. There was also a discrepancy between the perception of benefit from rehabilitation for the patient, and the caregiver's perception of benefit. Such questionnaires might be a useful addition to clinical trials to justify a treatment approval.

Patient reported outcomes are instrumental in getting drugs approved and we are seeing an increase in drugs approved just on quality of life (QoL) $)^{96,97}$. One hundred and eighty-nine CMT1A patients were recently reported to have a QoL that was significantly worse versus the standard population, albeit slightly better than patients with multiple sclerosis ${ }^{98}$. In this study women had earlier CMT1A onset, higher deterioration of the QoL and when assessed by the ONLS, higher disability of the upper limb ${ }^{98}$. A recent study of pain in 176 children with CMT used QoL outcomes and other clinical assessments ${ }^{99}$. It was shown that increased pain correlated with deteriorating QoL scores but not with more severe neuropathy. What could we do to improve QoL of patients with CMT? Clearly, in children steps to alleviate pain would be an improvement.

\section{Conclusion}

We have briefly summarized some of the developments in CMT research of the last few years. This follows on from a meeting organized by HNF to seek different perspectives which could help us understand what areas may need support and further research. We have also attempted to prioritize areas of CMT research based on the need to bring treatments to market for the waiting patients (Table 2).
Currently, CMT1A is the only type of CMT for which there is a therapeutic in clinical trials ${ }^{90,91}$. We need to ensure that this compound is successful because it will benefit the patient and CMT focused scientific community. In order to do this we may want to identify, develop and validate more robust outcome measures for CMT as described earlier. In addition to show the value of treatments and impact on the QoL of patients for insurance companies who would reimburse treatment we need more studies that look into this. Based on our priorities of helping to translate treatments to the clinic and help patients, we perhaps could focus on the development of new clinical endpoints and any efforts to improve and quantify the impact of CMT on patient QoL. If we are to impact patients with CMT it is important to diagnose their disease early and to do this accurately.

High to medium level priorities include efforts to find new treatments for other forms of CMT. This may require more collaborations to identify molecules for progression. Encouraging companies to collaborate is also in the best interests of the field but not without its complexities. We can be prepared for this by using software that enables secure collaboration between different parties earlier.

Certainly we still have only a partial understanding of CMT and the search for new mechanisms and targets would be important perhaps for future breakthroughs in treatment. Another important priority is to include recruiting more patients for future clinical trials as we may be underestimating the number of patients with CMT. Registries such as GRIN ${ }^{8}$ may help in this regard to both identify patients and understand their disease and treatment needs.

Table 2. Long and short term impacting priorities for CMT research.

\begin{tabular}{|c|c|}
\hline $\begin{array}{l}\text { Priority } \\
\text { Level }\end{array}$ & Projects \\
\hline \multirow[t]{5}{*}{ Highest } & $\begin{array}{l}\text { Ensure clinical trials for potential treatments for } \mathrm{CMT1A} \text { are successful and drugs are } \\
\text { approved rapidly by regulators. (Short term impact) }\end{array}$ \\
\hline & Develop sensitive, robust outcome measures for CMT. (Long term impact) \\
\hline & $\begin{array}{l}\text { Demonstrate the impact of therapeutics through a measurable impact on quality of life } \\
\text { of CMT patients. (Short term and long term impact) }\end{array}$ \\
\hline & Ensure early accurate diagnosis of patients with CMT. (Long term impact) \\
\hline & $\begin{array}{l}\text { Set up multiple HTS using FDA and proprietary compounds against various in vitro } \\
\text { models for different CMT forms. (Long term impact) }\end{array}$ \\
\hline \multirow[t]{5}{*}{ Medium } & Translate early mid stage preclinical discoveries for CMT. (Mid-long term impact) \\
\hline & $\begin{array}{l}\text { Prioritize promising preclinical candidates for other forms of CMT that can be quickly } \\
\text { assessed for efficacy in multiple in vivo animal models. (Long term impact) }\end{array}$ \\
\hline & Foster increased academic-industry-foundation collaborations. (Long term impact) \\
\hline & Identify new mechanisms and targets for treatment of CMT. (Long term impact) \\
\hline & Recruit patients through registries for future clinical trials. (Short term impact) \\
\hline \multirow[t]{2}{*}{ Lower } & Provide research materials and models in central repositories. (Long term impact) \\
\hline & Explore gene therapy and stem cells as longer term approaches. (Long term impact) \\
\hline
\end{tabular}


If we are to encourage more research on CMT, animal and cell models, chemicals and reagents need to be available readily and if possible centralized in a repository. Several animal and stem cell models have recently been developed, and it will be important to provide a repository so that other researchers can access them. Knowing which animal and cell models are valid and which are not could help to prevent costly clinical trials (as described for the ALS example earlier). While CMT is not a wide-spread disease and the funds available are limited, we have still to consider the development of such a repository for scientists because it would facilitate compound testing, and such repositories have been successfully developed for other diseases. As compounds like PXT-3003 progress through clinical trials and hopefully show an impact on the disease, other companies will likely show an interest in CMT. These companies will want to screen their libraries in cell and animal models. As we have seen in recent years, preclinical research is happening through collaboration with academic screening centers $^{100}$. It will be important therefore that as a community we fully characterize these systems and have them available for testing.

We should also be open to considering biotherapeutic approaches which could complement small molecule drugs. It would appear that there has been relatively little research in gene therapy for CMT. We could certainly leverage the considerable developments that have been occurring for other diseases in this regard. As a small rare disease foundation we have to consider carefully where we put our resources.

Clearly there are many other fascinating areas of research that are ongoing or may be required. The clinical trials for CMT recently undertaken are using relatively crude measures for determining efficacy. Longer-term assessments of patients using proteomic and metabolomic approaches may help to identify new biomarkers for CMT. In addition, the development of new scores for the disease ${ }^{101}$ as well as standardizing them across institutions is important. Developing and accessing approaches that offer a real-time readout on the disease in patients would also be valuable for future clinical trials.

From the diagnostic side it would appear that assessing just four genes including PMP22 duplication/deletions, GJB1, MPZ, and $M F N$, would capture most of the patients with a CMT phenotype. If we are to simplify diagnosis and perhaps reduce costs, a more simplistic algorithm is needed. What other factors may be important for CMT that could modify the disease or the QoL? For example a recent study of meal frequency from studies of animal and human subjects suggests that intermittent energy restriction can improve health indicators and counteract disease processes ${ }^{102}$. These changes in meal frequency could have an impact on overall health. Should we be studying the effect of this intermittent energy restriction on specific diseases like CMT also?

In summary, we have drawn attention to some of the most recent advances in CMT research and made suggestions of where funding bodies such as HNF could invest to have maximum short term impact (e.g. ensuring a treatment for CMT1A is approved quickly), as well as long term impact (e.g. prioritizing compounds for other forms of CMT) (Table 2). Our hope is that once a treatment for CMT1A is approved more drug companies will be interested in CMT, investment in research will increase and therefore we have to be prepared for that and the downstream implications on resources, research materials, researchers and ultimately patients themselves.

\section{Author contributions}

SE completed the first draft and coordinated the manuscript preparation. All authors contributed to the writing of the final manuscript.

\section{Competing interests}

$\mathrm{SE}$ is a consultant for CDD and employee of HNF, NL is an employee of CDD.

JJH is an employee of Quest Diagnostics.

HNF receives funding from Pharnext to support CMT education and awareness.

\section{Grant information}

The author(s) declared that no grants were involved in supporting this work.

\section{Acknowledgments}

This meeting was funded by the Hereditary Neuropathy Foundation.

SE kindly acknowledges discussions with Teri Rosenbaum-Chou and Blake Gudgel (Modus Health), Richard Harrison and Jennifer Berbaum (Thomson Reuters) as well as the considerable input and suggestions of Dr. Jun Li (Vanderbilt University).
1. Swinney DC, Xia S: The discovery of medicines for rare diseases. Future Med Chem. 2014; 6(9): 987-1002.

PubMed Abstract | Publisher Full Text

2. Groft SC: Rare diseases research: expanding collaborative translationa research opportunities. Chest. 2013; 144(1): 16-23. PubMed Abstract | Publisher Full Text | Free Full Text

3. Wood J, Sames L, Moore A, et al.: Multifaceted roles of ultra-rare and rare disease patients/parents in drug discovery. Drug Discov Today. 2013; 18(21-22): 1043-1051.

PubMed Abstract | Publisher Full Text

4. Might M, Wilsey M: The shifting model in clinical diagnostics: how next-generation sequencing and families are altering the way rare diseases are discovered, studied, and treated. Genet Med. 2014; 16(10): 736-7. PubMed Abstract | Publisher Full Text

5. Itoh T, Pleasure D: The future of research in neuropathy. JAMA Neurol. 2014 72(1): 5-7.

PubMed Abstract | Publisher Full Text

6. Miyamoto BE, Kakkis ED: The potential investment impact of improved access to accelerated approval on the development of treatments for low prevalence rare diseases. Orphanet J Rare Dis. 2011; 6: 49 PubMed Abstract | Publisher Full Text | Free Full Text

7. Beaulieu CL, Samuels ME, Ekins S, et al:: A generalizable pre-clinical research 
approach for orphan disease therapy. Orphanet J Rare Dis. 2012; 7: 39. PubMed Abstract | Publisher Full Text | Free Full Text

8. Sames L, Moore A, Arnold R, et al.: Recommendations to enable drug development for inherited neuropathies: Charcot-Marie-Tooth and Giant Axonal Neuropathy. F1000Res. 2014; 3: 83.

PubMed Abstract | Publisher Full Text | Free Full Text

9. Vaidya M: Ice bucket challenge cash may help derisk ALS drug research. Nat Med. 2014; 20(10): 1080

PubMed Abstract | Publisher Full Text

10. Scott S, Kranz JE, Cole J, et al.: Design, power, and interpretation of studies in the standard murine model of ALS. Amyotroph Lateral Scler. 2008; 9(1): 4-15.

PubMed Abstract | Publisher Full Text

11. Perrin S: Preclinical research: Make mouse studies work. Nature. 2014; 507(7493): 423-425.

PubMed Abstract | Publisher Full Text

12. Prinz F, Schlange T, Asadullah K: Believe it or not: how much can we rely on published data on potential drug targets? Nat Rev Drug Discov. 2011; 10(9): 712.

PubMed Abstract | Publisher Full Text

13. Baell JB, Holloway GA: New substructure filters for removal of pan assay interference compounds (PAINS) from screening libraries and for their exclusion in bioassays. J Med Chem. 2010; 53(7): 2719-2740. PubMed Abstract | Publisher Full Text

14. Baell J, Walters MA: Chemistry: Chemical con artists foil drug discovery. Nature. 2014; 513(7519): 481-3. PubMed Abstract | Publisher Full Text

15. Che J, King FJ, Zhou B, et al:: Chemical and biological properties of frequent screening hits. J Chem Inf Model. 2012; 52(4): 913-26. PubMed Abstract | Publisher Full Text

16. Sink R, Gobec $S$, Pečar $S$, et al:: False positives in the early stages of drug discovery. Curr Med Chem. 2010; 17(34): 4231-55.

PubMed Abstract | Publisher Full Text

17. Ekins S, Olechno J, Williams AJ: Dispensing processes impact apparent biological activity as determined by computational and statistical analyses. PLoS One. 2013; 8(5): e62325.

PubMed Abstract | Publisher Full Text | Free Full Text

18. McDonald GR, Hudson AL, Dunn SM, et al.: Bioactive contaminants leach from disposable laboratory plasticware. Science. 2008; 322(5903): 917. PubMed Abstract | Publisher Full Text

19. Sassano MF, Doak AK, Roth BL, et al:: Colloidal aggregation causes inhibition of G protein-coupled receptors. J Med Chem. 2013; 56(6): 2406-14. PubMed Abstract | Publisher Full Text | Free Full Text

20. Waybright TJ, Britt JR, McCloud TG: Overcoming problems of compound storage in DMSO: solvent and process alternatives. J Biomol Screen. 2009; 14(6): 708-15

PubMed Abstract | Publisher Full Text

21. Narang D, Kerr PM, Baserman J, et al.: Triton X-100 inhibits L-type voltageoperated calcium channels. Can J Physiol Pharmacol. 2013; 91(4): 316-24. PubMed Abstract | Publisher Full Text

22. Williams AJ, Ekins S, Tkachenko V: Towards a gold standard: regarding quality in public domain chemistry databases and approaches to improving the situation. Drug Discov Today. 2012; 17(13-14): 685-701. PubMed Abstract | Publisher Full Text

23. Southan C, Williams AJ, Ekins S: Challenges and recommendations for obtaining chemical structures of industry-provided repurposing candidates. Drug Discov Today. 2013; 18(1-2): 58-70.

PubMed Abstract | Publisher Full Text

24. Orchard S, A-Lazikani B, Bryant S, et al:: Minimum information about a bioactive entity (MIABE). Nat Rev Drug Discov. 2011; 10(9): 661-9. PubMed Abstract | Publisher Full Text

25. Shun TY, Lazo JS, Sharlow ER, et al.: Identifying actives from HTS data sets: practical approaches for the selection of an appropriate HTS data-processing method and quality control review. J Biomol Screen. 2011; 16(1): 1-14. PubMed Abstract | Publisher Full Text

26. Hert J, Irwin JJ, Laggner C, et al.: Quantifying biogenic bias in screening libraries. Nat Chem Biol. 2009; 5(7): 479-83. PubMed Abstract | Publisher Full Text | Free Full Text

27. Ekins $\mathrm{S}$, Waller $\mathrm{CL}$, Bradley MP, et al.: Four disruptive strategies for removing drug discovery bottlenecks. Drug Discov Today. 2013; 18(5-6): 265-71. PubMed Abstract | Publisher Full Text

28. Frye S, Crosby M, Edwards T, et al.: US academic drug discovery. Nat Rev Drug Discov. 2011; 10(6): 409-10.

PubMed Abstract | Publisher Full Text

29. Hay M, Thomas DW, Craighead JL, et al:: Clinical development success rates for investigational drugs. Nat Biotechnol. 2014; 32(1): 40-51. PubMed Abstract | Publisher Full Text

30. DiVincenzo C, Elzinga CD, Medeiros AC, et al:: The allelic spectrum of CharcotMarie-Tooth disease in over 17,000 individuals with neuropathy. Mol Genet Genomic Med. 2014; 2(6): 522-529.

PubMed Abstract | Publisher Full Text | Free Full Text
31. Miller LJ, Saporta AS, Sottile SL, et al.: Strategy for genetic testing in CharcotMarie-disease. Acta Myol. 2011; 30(2): 109-16.

PubMed Abstract | Publisher Full Text | Free Full Text

32. Rangaraju S, Verrier JD, Madorsky I, et al.: Rapamycin activates autophagy and improves myelination in explant cultures from neuropathic mice. $J$ Neurosci. 2010; 30(34): 11388-97.

PubMed Abstract | Publisher Full Text | Free Full Text

33. Kaya F, Belin S, Bourgeois $\mathrm{P}$, et al.: Ascorbic acid inhibits PMP22 expression by reducing cAMP levels. Neuromuscul Disord. 2007; 17(3): 248-53. PubMed Abstract | Publisher Full Text

34. England JD, Gronseth GS, Franklin G, et al.: Practice Parameter: evaluation of distal symmetric polyneuropathy: role of laboratory and genetic testing (an evidence-based review). Report of the American Academy of Neurology, American Association of Neuromuscular and Electrodiagnostic Medicine, and American Academy of Physical Medicine and Rehabilitation. Neurology. 2009; 72(2): 185-92.

PubMed Abstract | Publisher Full Text

35. Ostern R, Fagerheim $\mathrm{T}, \mathrm{Hj}$ ellnes $\mathrm{H}$, et al.: Diagnostic laboratory testing for Charcot-Marie-Tooth disease (CMT): the spectrum of gene defects in Norwegian patients with CMT and its implications for future genetic test strategies. BMC Med Genet. 2013; 14: 94. PubMed Abstract | Publisher Full Text | Free Full Text

36. Murphy SM, Laura M, Fawcett K, et al.: Charcot-Marie-Tooth disease: frequency of genetic subtypes and guidelines for genetic testing. $J$ Neurol Neurosurg Psychiatry. 2012; 83(7): 706-10.

PubMed Abstract | Publisher Full Text | Free Full Text

37. Saporta AS, Sottile SL, Miller LJ, et al.: Charcot-Marie-Tooth disease subtypes and genetic testing strategies. Ann Neurol. 2011; 69(1): 22-33. PubMed Abstract | Publisher Full Text | Free Full Text

38. Ylikallio E, Johari M, Konovalova S, et al.: Targeted next-generation sequencing reveals further genetic heterogeneity in axonal Charcot-Marie-Tooth neuropathy and a mutation in HSPB1. Eur J Hum Genet. 2014; 22(4): $522-7$.

PubMed Abstract | Publisher Full Text | Free Full Text

39. Yao P, Fox PL: Aminoacyl-tRNA synthetases in medicine and disease. EMBO Mol Med. 2013; 5(3): 332-43.

PubMed Abstract | Publisher Full Text | Free Full Text

40. Latour P, Thauvin-Robinet C, Baudelet-Méry C, et al:: A major determinant for binding and aminoacylation of tRNA(Ala) in cytoplasmic Alanyl-tRNA synthetase is mutated in dominant axonal Charcot-Marie-Tooth disease. Am Hum Genet. 2010; 86(1): 77-82.

Hum Genet. 2010; 86(1): 77-82.
PubMed Abstract | Publisher Full Text | Free Full Text

41. Jordanova A, Irobi J, Thomas FP, et al:: Disrupted function and axonal distribution of mutant tyrosyl-tRNA synthetase in dominant intermediate Charcot-Marie-Tooth neuropathy. Nat Genet. 2006; 38(2): 197-202. PubMed Abstract | Publisher Full Text

42. Antonellis A, Ellsworth RE, Sambuughin N, et al:: Glycyl tRNA synthetase mutations in Charcot-Marie-Tooth disease type 2D and distal spinal muscular atrophy type V. Am J Hum Genet. 2003; 72(5): 1293-9. PubMed Abstract | Publisher Full Text | Free Full Text

43. McLaughlin HM, Sakaguchi R, Liu C, et al:: Compound heterozygosity for lossof-function lysyl-tRNA synthetase mutations in a patient with peripheral neuropathy. Am J Hum Genet. 2010; 87(4): 560-6. PubMed Abstract | Publisher Full Text | Free Full Text

44. Gonzalez $\mathrm{M}$, McLaughlin $\mathrm{H}$, Houlden $\mathrm{H}$, et al:: Exome sequencing identifies a significant variant in methionyl-tRNA synthetase (MARS) in a family with lateonset CMT2. J Neurol Neurosurg Psychiatry. 2013; 84(11): 1247-9.

PubMed Abstract | Publisher Full Text | Free Full Text

45. Vester A, Velez-Ruiz G, McLaughlin HM, et al:: A loss-of-function variant in the human histidyl-tRNA synthetase (HARS) gene is neurotoxic in vivo. Hum Mutat 2013; 34(1): 191-9.

PubMed Abstract | Publisher Full Text | Free Full Text

46. Griffin LB, Sakaguchi R, McGuigan D, et al:: Impaired function is a common feature of neuropathy-associated glycyl-tRNA synthetase mutations. Hum Mutat. 2014; 35(11): 1363-71.

PubMed Abstract | Publisher Full Text | Free Full Text

47. Motley WW, Seburn KL, Nawaz MH, et al:: Charcot-Marie-Tooth-linked mutant GARS is toxic to peripheral neurons independent of wild-type GARS levels. PLoS Genet. 2011; 7(12): e1002399.

PubMed Abstract | Publisher Full Text | Free Full Text

48. Antonellis A, Lee-Lin SQ, Wasterlain A, et al:: Functional analyses of glycyltRNA synthetase mutations suggest a key role for tRNA-charging enzymes in peripheral axons. J Neurosci. 2006; 26(41): 10397-406.

PubMed Abstract | Publisher Full Text

49. Motley WW, Talbot K, Fischbeck KH: GARS axonopathy: not every neuron's cup of tRNA. Trends Neurosci. 2010; 33(2): 59-66.

PubMed Abstract | Publisher Full Text | Free Full Text

50. Fledrich R, Stassart RM, Sereda MW: Experimental Treatment of hereditary and acquired Neuropathies, in Pathological potential of neuroglia. V. Parpura and A. Verkhratsky, Editors. Springer. 2014; 437-472.

Publisher Full Text

51. Naef R, Suter U: Many facets of the peripheral myelin protein PMP22 in 
myelination and disease. Micros Res Tech. 1998; 41(5): 359-371. PubMed Abstract | Publisher Full Text

52. Fledrich R, Stassart RM, Klink A, et al:: Soluble neuregulin-1 modulates disease pathogenesis in rodent models of Charcot-Marie-Tooth disease 1A. Nat Med. 2014; 20(9): 1055-61.

PubMed Abstract | Publisher Full Text

53. Inglese J, Dranchak P, Moran JJ, et al:: Genome editing-enabled HTS assays expand drug target pathways for Charcot-Marie-tooth disease. ACS Chem Biol. 2014; 9(11): 2594-602.

PubMed Abstract | Publisher Full Text | Free Full Text

54. Jang SW, Lopez-Anido C, MacArthur R, et al:: Identification of drug modulators targeting gene-dosage disease CMT1A. ACS Chem Biol. 2012; 7(7): 1205-13. PubMed Abstract | Publisher Full Text | Free Full Text

55. Nicks J, Lee S, Harris A, et al.: Rapamycin improves peripheral nerve myelination while it fails to benefit neuromuscular performance in neuropathic mice. Neurobiol Dis. 2014; 70: 224-36. PubMed Abstract | Publisher Full Tex

56. Lee S, Amici S, Tavori H, et al.: PMP22 is critical for actin-mediated cellular functions and for establishing lipid rafts. J Neurosci. 2014; 34(48): 16140-52. PubMed Abstract | Publisher Full Text | Free Full Text

57. Rivieccio MA, Brochier C, Willis DE, et al:: HDAC6 is a target for protection and regeneration following injury in the nervous system. Proc Natl Acad Sci U S A 2009; 106(46): 19599-604.

PubMed Abstract | Publisher Full Text | Free Full Text

58. d'Ydewalle C, Krishnan J, Chiheb DM, et al:: HDAC6 inhibitors reverse axonal loss in a mouse model of mutant HSPB1-induced Charcot-Marie-Tooth disease. Nat Med. 2011; 17(8): 968-74

PubMed Abstract | Publisher Full Text

59. Zhu J, Chen W, Mi R, et al.: Ethoxyquin prevents chemotherapy-induced neurotoxicity via Hsp90 modulation. Ann Neurol. 2013; 74(6): 893-904. PubMed Abstract | Publisher Full Text

60. Chittoor-Vinod VG, Lee S, Judge SM, et al.: Inducible HSP70 Is Critical in Preventing the Aggregation and Enhancing the Processing of PMP22. ASN Neuro. 2015; 7(1): 1-17. PubMed Abstract | Publisher Full Text

61. Fledrich R, Stassart RM, Sereda MW: Murine therapeutic models for CharcotMarie-Tooth (CMT) disease. Br Med Bull. 2012; 102(1): 89-113. PubMed Abstract | Publisher Full Text

62. Klein D, Groh J, Wettmarshausen J, et al:: Nonuniform molecular features of myelinating Schwann cells in models for CMT1: distinct disease patterns are associated with NCAM and c-Jun upregulation. Glia. 2014; 62(5): 736-50. PubMed Abstract | Publisher Full Text

63. Bogdanik LP, Sleigh JN, Tian C, et al.: Loss of the E3 ubiquitin ligase LRSAM1 sensitizes peripheral axons to degeneration in a mouse model of CharcotMarie-Tooth disease. Dis Model Mech. 2013; 6(3): 780-92. PubMed Abstract | Publisher Full Text | Free Full Text

64. Seburn KL, Morelli KH, Jordanova A, et al:: Lack of neuropathy-related phenotypes in hint1 knockout mice. J Neuropathol Exp Neurol. 2014; 73(7): 693-701.

PubMed Abstract | Publisher Full Text | Free Full Text

65. Chapman AL, Bennett EJ, Ramesh TM, et al:: Axonal Transport Defects in a Mitofusin 2 Loss of Function Model of Charcot-Marie-Tooth Disease in Zebrafish. PLoS One. 2013; 8(6): e67276. PubMed Abstract | Publisher Full Text | Free Full Text

66. Cherry S, Jin EJ, Ozel MN, et al:: Charcot-Marie-Tooth 2B mutations in rab7 cause dosage-dependent neurodegeneration due to partial loss of function. Elife. 2013; 2: e01064.

PubMed Abstract | Publisher Full Text | Free Full Text

67. Janssens K, Goethals S, Atkinson D, et al:: Human Rab7 mutation mimics features of Charcot-Marie-Tooth neuropathy type 2B in Drosophila. Neurobiol Dis. 2014; 65: 211-9.

PubMed Abstract | Publisher Full Tex

68. Ermanoska B, Motley WW, Leitão-Gonçalves R, et al:: CMT-associated mutations in glycyl- and tyrosyl-tRNA synthetases exhibit similar pattern of toxicity and share common genetic modifiers in Drosophila. Neurobiol Dis. 2014; 68 $180-9$.

PubMed Abstract | Publisher Full Text | Free Full Text

69. Storkebaum E, Leitão-Gonçalves R, Godenschwege T, et al.: Dominant mutations in the tyrosyl-tRNA synthetase gene recapitulate in Drosophila features of human Charcot-Marie-Tooth neuropathy. Proc Natl Acad Sci U S A. 2009; 106(28): 11782-7.

PubMed Abstract | Publisher Full Text | Free Full Text

70. Sahenk Z, Galloway G, Clark KR, et al.: AAV1.NT-3 gene therapy for CharcotMarie-Tooth neuropathy. Mol Ther. 2014; 22(3): 511-21.

PubMed Abstract | Publisher Full Text | Free Full Text

71. Mussche S, Devreese B, Nagabhushan Kalburgi S, et al:: Restoration of cytoskeleton homeostasis after gigaxonin gene transfer for giant axonal neuropathy. Hum Gene Ther. 2013; 24(2): 209-19.

PubMed Abstract | Publisher Full Text

72. Inoue $\mathrm{H}, \mathrm{Nagata} \mathrm{N}$, Kurokawa $\mathrm{H}$, et al:: iPS cells: a game changer for future medicine. EMBO J. 2014; 33(5): 409-17.

PubMed Abstract | Publisher Full Text | Free Full Text

73. Yamanaka S: Induced pluripotent stem cells: past, present, and future. Cell
Stem Cell. 2012; 10(6): 678-84.

PubMed Abstract | Publisher Full Text

74. Surani MA: Cellular reprogramming in pursuit of immortality. Cell Stem Cell. 2012; 11(6): 748-50.

PubMed Abstract | Publisher Full Text

75. Wu SM, Hochedlinger K: Harnessing the potential of induced pluripotent stem cells for regenerative medicine. Nat Cell Biol. 2011; 13(5): 497-505. PubMed Abstract | Publisher Full Text | Free Full Text

76. Johnson-Kerner BL, Ahmad FS, Diaz AG, et al.: Let allntermediate filament protein accumulation in motor neurons derived from giant axonal neuropathy iPSCs rescued by restoration of gigaxonin. Hum Mol Genet. 2014; 24(5): 1420-31.

PubMed Abstract | Publisher Full Text

77. Saporta MA, Dang V, Volfson D, et al:: Axonal Charcot-Marie-Tooth disease patient-derived motor neurons demonstrate disease-specific phenotypes including abnormal electrophysiological properties. Exp Neurol. 2015; 263 : 190-9.

PubMed Abstract | Publisher Full Text | Free Full Text

78. Ma MS, Boddeke E, Copray S: Pluripotent Stem Cells for Schwann Cell Engineering. Stem Cell Rev. 2014.

PubMed Abstract | Publisher Full Text

79. Liu Q, Spusta SC, Mi R, et al:: Human neural crest stem cells derived from human ESCs and induced pluripotent stem cells: induction, maintenance, and differentiation into functional schwann cells. Stem Cells Transl Med. 2012; 1(4): 266-78.

PubMed Abstract | Publisher Full Text | Free Full Text

80. Menendez L, Kulik MJ, Page AT, et al.: Directed differentiation of human pluripotent cells to neural crest stem cells. Nat Protoc. 2013; 8(1): 203-12. PubMed Abstract | Publisher Full Text

81. Ekins S, Clark AM, Swamidass SJ, et al:: Bigger data, collaborative tools and the future of predictive drug discovery. J Comput Aided Mol Des. 2014; 28(10): 997-1008.

PubMed Abstract | Publisher Full Text | Free Full Text

82. Litterman NK, Ekins S: Databases and collaboration require standards for human stem cell research. Drug Discov Today. 2015; 20(2): 247-254. PubMed Abstract | Publisher Full Text

83. Anon : NIH Blueprint Neurotherapeutics Network. Neuroscience research. 2014 Reference Source

84. Hohn M, Gregory K, Chibale K, et al:: Novel web-based tools combining chemistry informatics, biology and social networks for drug discovery. Drug Discov Today. 2009; 14(5-6): 261-70.

PubMed Abstract | Publisher Full Tex

85. Ekins S, Williams AJ, Krasowski MD, et al.In silico repositioning of approved drugs for rare and neglected diseases. Drug Discov Today. 2011; 16(7-8): 298-310.

PubMed Abstract | Publisher Full Text

86. Litterman NK, Lipinski CA, Bunin BA, et al:: Computational prediction and validation of an expert's evaluation of chemical probes. $J$ Chem Inf Model. 2014; 54(10): 2996-3004.

PubMed Abstract | Publisher Full Tex

87. Dortch RD, Dethrage LM, Gore JC, et al: Proximal nerve magnetization transfe MRI relates to disability in Charcot-Marie-Tooth diseases. Neurology. 2014; 83(17): 1545-53.

PubMed Abstract | Publisher Full Text | Free Full Text

88. Fridman V, Bundy B, Reilly MM, et al:: CMT subtypes and disease burden in patients enrolled in the Inherited Neuropathies Consortium natural history study: a cross-sectional analysis. J Neurol Neurosurg Psychiatry. 2014. PubMed Abstract | Publisher Full Text

89. Anon. Addex Announces Positive Data with ADX71441 in a Pre-Clinical Transgenic Model of Charcot-Marie-Tooth 1A Disease, Addex press release. 2013.

Reference Source

90. Chumakov I, Milet A, Cholet N, et al.: Polytherapy with a combination of three repurposed drugs (PXT-3003) down-regulates Pmp22 over-expression and improves myelination, axonal and functional parameters in models of CMT1A neuropathy. Orphanet J Rare Dis. 2014; 9(1): 201. PubMed Abstract | Publisher Full Text | Free Full Text

91. Attarian $\mathrm{S}$, Vallat JM, Magy L, et al.: An exploratory randomised double-blind and placebo-controlled phase 2 study of a combination of baclofen, naltrexone and sorbitol (PXT-3003) in patients with Charcot-Marie-Tooth disease type 1A. Orphanet J Rare Dis. 2014; 9(1): 199.

PubMed Abstract | Publisher Full Text | Free Full Text

92. Tulchin-Francis KW, Stevens $\mathrm{W}$ Jr, Jeans KA, et al.: Intensity and duration of activity bouts decreases in healthy children between 7 and 13 years of age a new higher resolution method to analyze StepWatch Activity Monitor data. Physiol Meas. 2014; 35(11): 2239-54.

PubMed Abstract | Publisher Full Text

93. Schmidt AL, Pennypacker ML, Thrush AH, et al.: Validity of the StepWatch Step Activity Monitor: preliminary findings for use in persons with Parkinson disease and multiple sclerosis. $J$ Geriatr Phys Ther. 2011; 34(1): 41-5. PubMed Abstract | Publisher Full Text

94. Mannil M, Solari A, Leha A, et al.: Selected items from the Charcot-Marie-Tooth (CMT) Neuropathy Score and secondary clinical outcome measures serve as sensitive clinical markers of disease severity in CMT1A patients. Neuromuscul 
Disord. 2014; 24(11): 1003-17. PubMed Abstract | Publisher Full Text

95. Padua L, Pazzaglia C, Schenone A, et al:: Rehabilitation for Charcot-Marie-Tooth a survey study of patients and familiar/caregiver perspective and perception of efficacy and needs. Eur J Phys Rehabil Med. 2014; 50(1) 25-30. PubMed Abstract

96. Beitz J, Gnecco C, Justice R: Quality-of-life end points in cancer clinical trials: the U.S. Food and Drug Administration perspective. J Natl Cancer Inst Monogr. 1996; 20: 7-9.

PubMed Abstract

97. Shah SN, Sesti AM, Copley-Merriman K, et al:: Quality of life terminology included in package inserts for US approved medications. Qual Life Res. 2003 12(8): 1107-17.

PubMed Abstract | Publisher Full Text

98. Colomban C, Micallef J, Lefebvre MN, et al:: Clinical spectrum and gende differences in a large cohort of Charcot-Marie-Tooth type 1A patients. J Neurol Sci. 2014; 336(1-2): 155-60.

PubMed Abstract | Publisher Full Text

99. Ramchandren S, Jaiswal M, Feldman E, et al.: Effect of pain in pediatric inherited neuropathies. Neurology. 2014; 82(9): 793-7. PubMed Abstract | Publisher Full Text | Free Full Text

100. Ekins S, Waller CL, Bradley MP, et al.: Four disruptive strategies for removing drug discovery bottlenecks. Drug Disc Today. 2013; 18(5-6): 265-271. PubMed Abstract | Publisher Full Tex

101. Murphy SM, Herrmann DN, McDermott MP, et al:: Reliability of the CMT neuropathy score (second version) in Charcot-Marie-Tooth disease. $J$ Peripher Nerv Syst. 2011; 16(3): 191-8.

PubMed Abstract | Publisher Full Text | Free Full Text

102. Mattson MP, Allisonc DB, Fontana $\mathrm{L}$, et al:: Meal frequency and timing in health and disease. Proc Natl Acad Sci U S A. 2014; 111(47): 16647-53. PubMed Abstract | Publisher Full Text | Free Full Text

103. Kaya F, Belin S, Diamantidis G, et al.: Ascorbic acid is a regulator of the intracellular cAMP concentration: old molecule, new functions? FEBS Lett. 2008; 582(25-26): 3614-8.

PubMed Abstract | Publisher Full Text

104. Anon. Dose Dependently Reduced PMP22 Expression Comparable to Baclofen in a Pre-Clinical Transgenic Model of Charcot-Marie-Tooth 1A Disease. Addex Therapeutics. 2013.

Reference Source 


\section{Open Peer Review}

\section{Current Peer Review Status:}

\section{Version 1}

Reviewer Report 01 April 2015

https://doi.org/10.5256/f1000research.6604.r7845

(c) 2015 Said G. This is an open access peer review report distributed under the terms of the Creative Commons Attribution License, which permits unrestricted use, distribution, and reproduction in any medium, provided the original work is properly cited.

\section{Gerard Said}

Department of Neurology, Hôpital Pitié-Salpêtrière, Paris, 75013, France

The authors discuss the many issues that can complicate the discovery of new drugs.

The authors summarize recent developments in Charcot-Marie-Tooth disease which may be used as an example of what can or should be done to improve development of drugs in rare disease.

The vast majority of CMT patients have copy number variations of PMP22. The authors propose a method destined to accelerate the identification of the different mutations associated with the CMT phenotype.

The authors briefly review the treatment used in CMT1A rat models and consider their application to humans.

Recently association of small doses of baclofen, naltrexone and sorbitol (PXT-3003) seemed promising and well tolerated. Phase 3 study is going to start in 2015, and it will take several years before a significant effect of the medication on CMT1A can be confirmed and the drug approved for treatment.

The different methods of evaluation of the benefit of treatment are discussed. In addition, it must be kept in mind that CMT1A is a very slowly progressive disease, with phenotypic variations especially in presentation and course. A large number of patients carrying the same mutation thus need to be included in the studies and followed over many years. It will not be an easy task in a rare disease.

This paper is useful in delineating the different steps that can lead to discovery of new drug in rare diseases, emphasizing the need for collaboration between geneticists, biochemists, drug companies and clinicians

Competing Interests: No competing interests were disclosed. 


\section{I confirm that I have read this submission and believe that I have an appropriate level of expertise to confirm that it is of an acceptable scientific standard.}

Reviewer Report 17 March 2015

https://doi.org/10.5256/f1000research.6604.r7842

(C) 2015 Mirsky R. This is an open access peer review report distributed under the terms of the Creative Commons Attribution License, which permits unrestricted use, distribution, and reproduction in any medium, provided the original work is properly cited.

\section{Rhona Mirsky}

Department of Cell and Developmental Biology, University College London, London, UK

This report reviews recent research on Charcot-Marie-Tooth neuropathies. The report is the result of a recent meeting of the scientific advisory board of the Hereditary Neuropathy Foundation and summarises suggestions made there. The article includes suggestions for improvements to diagnosis, including stratified testing for the most common mutations before screening for the rarer ones, and discussion of new and old animal models that have been developed to study and understand disease mechanisms and for the exploration of possible therapeutic strategies. It reviews other avenues of active research, including selective use of adenoviral vectors and stem cells that are being investigated for possible use in gene therapy for some forms of the disease, for understanding disease mechanisms, and for screening programmes for therapeutic drugs. It highlights the possibility that chemotherapy-induced toxicity may exacerbate some forms of CMT. It suggests that there is room for improved collaboration between different research groups and clinicians and more use of computational approaches. To my knowledge there are already several consortia in addition to the Hereditary Neuropathy Foundation that are already very active in trying to advance therapeutic strategies so I am not sure how much of a deficit there is in this area. On the clinical side a need for reliable biomarkers of the various disease forms is highlighted and the review ends with a discussion of clinical trials and the importance of involving patients and caregivers in the trial outcome measures is emphasised.

Overall the article provides an up to date review of the research and possible treatments for this group of relatively rare diseases which will be of use to both researchers and clinicians in the field.

Competing Interests: No competing interests were disclosed.

I confirm that I have read this submission and believe that I have an appropriate level of expertise to confirm that it is of an acceptable scientific standard. 
The benefits of publishing with F1000Research:

- Your article is published within days, with no editorial bias

- You can publish traditional articles, null/negative results, case reports, data notes and more

- The peer review process is transparent and collaborative

- Your article is indexed in PubMed after passing peer review

- Dedicated customer support at every stage

For pre-submission enquiries, contact research@f1000.com 